Arhe XVI, 31/2019

UDK 111:81’366.52

$1: 141.72$

DOI https://doi.org/10.19090/arhe.2019.31.171-188

Originalni naučni rad

Original Scientific Article

\author{
MILENA KARAPETROVIĆ ${ }^{1}$ \\ Univerzitet u Banjoj Luci, Filozofski fakultet
}

\title{
ONTOLOGIJA RODA: FEMINISTIČKO RAZUMIJEVANJE FILOZOFIJE
}

\begin{abstract}
Sažetak: Uspostavljanje roda kao analitičke kategorije znatno je uticalo na rasprave o svim važnim problemima unutar humanističkih i društvenih nauka, ali i dalje se ovaj pojam radije zaobilazi nego što je uključen u glavne struje filozofskih rasprava. Iako su feministička filozofija i filozofija roda ušle u okvire kurikuluma na mnogim svjetskim univerzitetima, još uvijek u filozofiji ostaju na marginama i u vlastitim zaštićenim prostorima. Umjesto usmjeravanja interesovanja na otvoreno pitanje o razlozima zanemarivanja feminističkih i rodnih teorija u filozofiji, ovdje će biti razmatran važan zaokret unutar samih tih teorija koji istovremeno predstavlja čvorište u njihovom razvoju. Riječ je o feminističko-filozofskom konceptu Džudit Batler, predstavljenom prije tri decenije, koji i danas daje podsticaje za nova pozicioniranja uprkos nevoljama koje donosi. Istraživanje u ovom radu prvenstveno je uokvireno njenim djelima: Nevolje $s$ rodom (Gender Trouble), Tijela koja nešto znače (Bodies that Matter) i Raščinjavanje roda (Undoing Gender).
\end{abstract}

Ključne riječi: feminizam, rod, pol, performativnost, Drugost, subjekt, tijelo

U jednom od svojih eseja filozofkinja i feministička teoretičarka Džudit Batler (Judith Butler) postavlja pitanje: „Može li 'Druga' filozofije govoriti?‘² Neophodnost pozicioniranja unutar filozofije ili na njenim rubovima, otvorenim prema interdisciplinarnim poljima, ukazuju na stalno suočavanje sa preprekama koje postavljaju pripadnici glavnih

\footnotetext{
${ }^{1}$ E-mail adresa autorke: milena.karapetrovic@ff.unibl.org

2 Butler, J., „Može li 'Druga' filozofije govoriti?“" u Raščinjavanje roda, Šahinpašić, Sarajevo 2005., str. 205.
} 
tokova filozofije čvrsto privrženi kanonima i jasno utvrđenim granicama (bez obzira da li je riječ o analitičkoj ili kontinentalnoj evropskoj filozofiji). Odnosi se to na svaki pokušaj promišljanja koji prekoračuje te granice, na svaki izlazak izvan datog i zadatog diskurzivnog područja, na sva nastojanja da se teorija izloži životu i stvarnosti. Ovdje sada posebno naglašavamo i odrednice - filozofkinja i feministička teoretičarka, jer upravo takvo imenovanje i stavljanje u jasne okvire otvara ključna pitanja u napetom odnosu filozofije i feminizma. Dodatno usložnjavanje predstavlja stavljanje odrednice feministička filozofkinja. Feministička filozofija jeste pronašla svoje mjesto kao pravac unutar savremene filozofije, ali prije svega zahvaljujući filozofkinjama samim, njeno priznanje od kanonske filozofije i dalje ostaje upitno.

To je i Džudit Batler navelo da u već spomenutom eseju naglasi: ,ja ne živim, ne pišem i ne radim untar institucija filozofije već nekoliko godina ${ }^{\text {“3 }}$. To institucionalno premještanje i smještanje u neko drugo polje, ne znači i izmještanje iz filozofije, bez obzira koliko to htjeli ili željeli „profesionalni mislioci (filozofi)“ koje često spominje još jedna filozofkinja koja po vlastitom priznanju nije okrenuta feminizmu, a pita se koliko je još i filozofkinja. ${ }^{4}$ I Batler i Hana Arent (Hannah Arendt) na različite načine pokazuju upravo koliko to što same priznaju da su odlučile da odstupaju dalje od zacrtane granice ali i da se istovremeno stalno vraćaju filozofiji, otvara prostore moguće slobode. Uostalom, primjer je to koji daje već Simon de Bovoar (Simone de Beauvoir) sa Drugim polom. Ni za jednu od ovih filozofkinja to nije poništavanje filozofije, njeno unižavanje, ili potpuno prelaženje na neku drugu stranu, to je način da se pokaže teškoća istovremenog bivanja kako u eteričnom svijetu spekulativnog mišljenja, tako i u svijetu stvarnosti koji je čvrsto vezan za svakodnevni život, djelovanje u najopštijem smislu i osjećaj odgovornosti prema zajednici. „Ne smijemo zaboraviti ni to da ontičko i ontološko, bez obzira na svu moć apstrahovanja i pokušaj približavanja

\footnotetext{
${ }^{3}$ Ibid., str. 205.

${ }^{4}$ Arent, H., Život duha, Službeni glasnik i Alexandria Press, Beograd 2010., str. 13.
} 
duhu i umu u najopštijem obliku, nije i ne može biti odvojeno od etičkog, političkog i društvenog. “5

Zadržavanje na sukobu filozofskog i feminističkog svakako ostaje bitno sporno pitanje, ali više kao neophodna naznaka za svako otvaranje značajnih rasprava iz oblasti feminističke filozofije. Važnijim zadatkom se čini ukazati na to šta feministička teorija, posebno njen posljednji veliki zaokret sa teorijom Džudit Batler, donosi kao poklon Drugog onom Prvom u filozofiji. U ovom tekstu ukazujemo na bitne probleme koji se otvaraju u filozofiji sa uspostavljanjem drugačijeg tumačenja odnosa pola i roda, pri čemu je u drugom planu značaj tog zaokreta unutar samih feminističkih teorija s obzirom na brojne rasprave koje je već proizvelo u prethodne tri decenije.

U prvom poglavlju naglasak je na razlozima za uspostavljanje nove koncepcije roda $\mathrm{u}$ feminizmu, a u drugom poglavlju predočene su osnovne postavke pojma roda prema teoriji Džudit Batler. Treće poglavlje otvara pitanja drugačijeg viđenja subjekta u savremenosti. Pokušaj razumijevanja Druge, koja je istovremeno i subjekt filozofiranja, i predmet o kome se filozofira uvijek otvara nove metodološke nedoumice unutar filozofije. Razmatranje se zato zadržava i povremeno biva zarobljeno u krugovima dekonstrukcije u kome Ja nema zaštitu čvrsto utemeljenog i ograničenog subjekta, već je i samo podložno tom dekonstruktivnom postupku.

\section{(NE)RASKIDIVA VEZA POLA I RODA}

Izrazito brz i dinamičan razvoj feminizma unutar svega nekoliko decenija, u odnosu na već uspostavljene i jasno uokvirene oblasti u društvenim i humanističkim naukama, značio je preplitanje dva suprotstavljena procesa: stvaranje novih pojmova, kao i njihovu istovremenu nadogradnju, preispitivanje i dekonstruisanje. Nekoliko je razloga za to: utemeljenje oblasti koja je i interdisciplinarna i

\footnotetext{
${ }^{5}$ Karapetrović, M., U lavirintima bića. Ontološka rasprava, Filozofski fakultet Univerzitet u Banjoj Luci i Grafid, Banja Luka 2014., str. 132.
} 
multidisciplinarna i transdisciplinarna; aktivističko djelovanje koje se prepliće sa teorijskim radom; izgradnja metoda kako na temelju tradicionalne metodologije tako i primjenom dekonstrukcije i genealogije; žive debate i diskusije koje ne dozvoljavaju zatvaranje u uske okvire; preispitivanje do tada nedodirljivih pojmova objektivnost $\mathrm{i}$ univerzalnosti u nauci, razmatranje uloge onog/one koji/a proizvodi teoriju. Sve to uslovilo je da upravo glavni pojmovi na kojima počivaju feminističke teorije budu prvi koji će biti kritički ispitivani.

Činilo se da će ukazivanje na razliku pol - rod biti glavna osnova daljeg razvoja feminističkih teorija, ali brojna otvorena pitanja su dovela do novog razvijanja teorija koju ide dalje od samog binarnog određenja. Upravo uspostavljanje roda kao glavne analitičke kategorije, te načini na koji se sada razmatra rod, posebno sa preokretom kroz teoriju Džudit Batler, uslovili su i postavljanje pitanja: Šta zapravo jeste subjekt i kako je moguće njegovo definisanje danas $u$ odnosu na odrednice ponuđene $u$ tradicionalnoj filozofiji? Na koji način uopšte možemo govoriti o identitetu? Osnova za to već je bila postavljena sa socijalnim konstruktivizmom $\mathrm{u}$ društvenim naukama, poststrukturalističkim debatama, te uvođenjem dekonstrukcije u filozofiju.

Umjesto zaokruživanje nove ontologije roda koja bi mogla biti ograničena i sputana već postojećim objašnjenjima filozofskih pojmova, Batler će u pomaku prema polju lingvističkog i kulturološkog radije govoriti o ,genealogiji ontologije roda“6. Diskurs i diskurzivne prakse su te koje stoje u centru analize, jer upravo preko njih, kako je pokazao Mišel Fuko (Michel Foucault), sagledavamo nove odnose moći. Ti odnosi ne utiču na (ljudsko) biće samo spolja nego postaju dio njegove osnove koja odavno više nije jedinstvena već je obilježena napuklinama. Imajući sve to u vidu, prije će se govoriti o „feminističkoj genealogijic“7 koja može ponuditi odgovarajući pristup. Za Džudit Batler nije moguće odogovoriti na pitanje - šta je rod - ne samo ako ostajemo u polju

\footnotetext{
${ }^{6}$ Batler, Dž., Nevolja s rodom. Feminizam i subverzija identiteta, Karpos, Loznica 2010., str. 104.

${ }^{7}$ Ibid., str. 55.
} 
institucionalne filozofije, već ostajemo li i u ranije uspostavljenim okvirima feminističkih teorija.

Preciziranje pojmova i insistiranje na njihovim čvrstvo utvrđenim značenjima može se pokazati pogubnim za feminizam, te je jedini način dekonstruisati ih u momentu dok još nastaju, dok do kraja nisu završeni, dok još nisu okoštali. Sama početna tačka procesa formulisanja mora postojati, ali sve ono što se širi oko toga ostaje upitno i uvijek podložno promjeni. Ovdje se ne radi ni o potpunom pristajanju na već definisani konstruktivizam i zarobljenost unutar debata na liniji konstruktivizam esencijalizam, već o nastojanju da se ta podjela prevaziđe kako nepotrebno ne bi ograničavala samo istraživanje. Za tu svrhu važno je ne zaboraviti i pitanja: „Kako i kada dolazi do konstrukcije roda? Kako razumeti konstrukciju u kojoj se ne može pretpostaviti ljudski konstruktor koji prethodi samoj konstrukciji?" ${ }^{8}$. Dakle, ono esencijalno svakako treba rasklopiti, sagledati posljedice tog rasklapanja, napraviti nove formulacije kad ostanemo na tim „kružnim razvalinama savremene rasprave“ ${ }^{\text {‘9 }}$, ali ne možemo do kraja ostati ni pri ponuđenom i datom usko okvirenom viđenju konstruisanja. Dekonstrukcija je ono što nas čuva, kako od mahnitosti konstruisanja koje ide u beskraj bez jasnih pravila, tako i od konstruisanja koje silom uspostavlja obrasce za biće i život određujući nove hegemonističke strukture od kojih smo nastojali pobjeći. Istovremeno, moramo biti svjesni granica dekonstrukcije same.

Praveći odmak od pitanja o načinima pristupanja i metodološkim obrascima sada treba sagledati sam pojam roda. To je moguće tek kad ga pokažemo kao autonomnog, nezavisnog u odnosu na pol, kao ono što se može a i ne mora podudarati sa polom. Jer tijela kao ono glavno što predstavlja biološko bivaju prisilno svrstana unutar zagrada koje ih ograničavaju i u stvarnom svijetu vode na granice, bilo žrtvovanja bilo otpora, s obzirom da odudaraju od tražene i očekivane normalnosti i od uloge koja im je unaprijed zadata. To nije traženje nasilnog rascijepa, već ono što se primjećuje sa daljim razvojem feminističkih teorija.

\footnotetext{
${ }^{8}$ Ibid., str. 59.

${ }^{9}$ Ibid., str. 59.
} 
Pol i rod treba posmatrati odvojeno kako se ne bi ostalo upravo na binarnim i hijerarhijskim pozicijama koje su predmet glavnih kritika feminizma. Odnos pola i roda ne može se zadržati na liniji priroda kultura, jer možda je i pol kao i rod „u jednakoj meri kulturno konstruisan““10. Osim toga, ostaje pri viđenju pola kao onog pasivnog, onog na šta se djeluje, kao onog što nema svoj život, te zapadamo u skoro istu relaciju kao kada na patrijarhalnim osnovama opisujemo odnos muškarac - žena. Potpuno vezivanje pola i roda ne daje ni dovoljno mogućnosti da se promisli o tome šta je uistinu (ženski) subjekt i na koji način, ako uopšte možemo, treba da govorimo o ženskom identitetu. Mnoge rasprave, koje su se vodile i vode unutar feminističkih krugova upravo u vezi ovog glavnog pojma, za Džudit Batler su predstavljale jedan od ključnih motiva da traži ,radikalno drugačije promišljanje kategorija identiteta u kontekstu odnosa radikalne asimetrije ${ }^{\text {‘11 }}$.

Ostajanje pri nekritičkom prihvatanju stavova feminističkih teoretičarki iz prvih generacija značilo bi ostati zarobljen u Drugosti. Dok je Drugost na početku radila upravo u korist razvoja novih teorija pokazujući da postoji ne ono, nego Ona ili One, koje su potpuno izdvojene, neprimjetne, kao ostatak onog Prvog, to je imalo snagu glavnog određenja kojim je bilo jedino moguće suprotstaviti se moći patrijarhalne kulture. Sada odbrana Drugosti bez ostatka može voditi tek zatvaranju feminističke teorije u još manji prostor, te je neophodno dekonstruisati i Drugost samu. O ograničenjima Drugosti naznaku ostavlja još Simon de Bovoar: „Ali pokušaj da bude žena jeste isto tako varka: biti žena značilo bi biti objekat, Drugo. A Drugo ostaje subjekat u svom otuđenju. "12 Čvrsto se držati Drugosti ostavlja mogućnost da to drugo ostane u svom odvojenom svijetu i da dalje postoji opasnost da ga ono Prvo podređuje, osvaja i da ta Drugost biva oživljena i unutar samog feminizma.

Pokazalo se to na primjeru slike žene koja obuhvata samo bijelu ženu, obrazovanu, finansijski obezbjeđenu, smještenu negdje na Zapadu.

\footnotetext{
${ }^{10}$ Ibid., str. 58.

${ }^{11}$ Ibid., str. 65.

${ }^{12}$ Bovoar, S. de, Drugi pol, I tom, BIGZ, Beograd 1982., str. 75.
} 
Upravo na (neo)kolonijalizam i unutar feminističkih teorija, kao i na zamke dekonstrukcije i spornih interpretacija koje treba izbjeći upozorava Gajatri Čakravorti Spivak (Gayatri Chakravorty Spivak): „mi koji se bavimo mestom drugog kao implicitnim 'subjekt'(ivnim) mestom, takođe moramo da menjamo svoje pretpostavke u zavisnosti od teksta kojim se bavimo“"13. Osim toga, ostati kod Drugog znači i odvojiti žensko/ženskost (feminino) i muško/muškost (maskulino) kao obilježja koja se u potpunosti preklapaju sa granicama pola i roda, ali i međusobnih odnosa nužno zasnovanih na heteroseksualnoj matrici ${ }^{14}$. Kako Batler naglašava, glavna namjera njenog rada u Nevolji s rodom jeste proširivanje granica razumijevanja kategorije roda, što vodi upravo ka novim teoretskim pozicijama: „Kada se konstruisani status roda teorijski ustanovi kao radikalno nezavisan od pola, sam rod postaje veštačka tvorevina bez uporišta i, shodno tome, muškarac i muževno jednako bi lako mogli da označavaju i žensko i muško telo, a žena i ženstveno muško u istoj meri u kojoj i žensko telo.“15

Odbacujući sigurna uporišta prethodnih feminističkih teorija i odbijajući da se zadrži na osiguranim pozicijama omeđenim podjelom pol/rod, određenjem ženskog identiteta i razvijanjem diskusije o Drugosti, Džudit Batler otvara prostor za razmatranje same kategorije roda. Ako rod više nije shvaćen kao društveni konstrukt čvrsto vezan za pol razumljen tek kao puko biološko, onda je neophodno pronaći drugačiji pristup za njegovo određenje. Konstrukcija jeste, ali ostaju pitanja: Koliko često se ta konstrukcija mijenja? Ko je uopšte stvara? Ko određuje ko jeste unutar te konstrukcije i na koji način? Tu više nije dovoljno samo odmaknuti se na rub jedne istraživačke oblasti, već učiniti još jedan korak dalje i uputiti se u središte presijecanja filozofskog, kulturološkog, lingvističkog, političkog. Analiza Džudit Batler potpuno je oslonjena na glavne stavove Mišela Fukoa, koji se mogu sažeti na sljedeće odrednice: vlast koja ima moć uvijek direktno utiče na tijelo;

${ }^{13}$ Spivak, G. Č., Kritika postkolonijalnog uma, Beogradski krug, Beograd 2003., str. 28.

${ }^{14}$ Batler, Dž., Nevolja s rodom. Feminizam i subverzija identiteta, str. 54.

${ }^{15}$ Ibid., str. 56. 
„odnosi moći isprepleteni [su] sa drugim tipovima odnosa (proizvodnim, srodničkim, porodičnim, seksualnim)“; zabrane i kazne koju moć proizvodi imaju različite oblike; moć je zasnovana na strategiji i njena dominacija se iskazuje kroz brojne procedure koje nije uvijek lako razaznati; moć jeste vezana i za ekonomsko; prepoznavanje djelovanja moći uvijek otvara i prostor za stvaranje otpora. ${ }^{16}$ Upravo je rod kao kategorija podesan da se pokaže na koji način moć funkcioniše i na koji način se različiti oblici moći ukrštaju i proizvode potčinjavanje.

\section{ROD - MJESTO MOĆI, MJESTO OTPORA}

S obzirom na temu ovog teksta ovdje se ne upuštamo $u$ rezimiranje opsežnih argumenata u feminističkim debatama o odnosu pola i roda i shvatanju roda kao esencijalnog ili nečeg što se konstruiše ${ }^{17}$ već ostajemo pri formulisanju roda onako kako ga predstavlja Džudit Batler. To znači vratiti se na početak knjige koja je izazvala najviše debata - Nevolja s rodom, kako bismo zajedno sa autorkom pratili razvoj cijelog koncepta i u njenim kasnijim knjigama i tekstovima koji predstavljaju stalni dijalog sa teoretičarima sličnih ili potpuno suprotnih stavova. Sporno je ponovo samo imenovanje - problem roda ovdje je nazvan - nevoljom. Naime, u debatama o pojmu roda i same feminističke teoretičarke nisu se usuđivale da naglase da samo to neslaganje jeste problem. Batler korištenjem ovog svakodnevnog izraza kao da nastoji da ublaži ono što se napokon mora reći - ako feminističke teorije žele ostati vitalne moraju na vrijeme da pruže otpor stvaranju vlastitih kanona. Zato treba izazivati nevolju, stvarati nevolju, biti nevolja. „Iako je ozbiljan koliko i smešan, a feminizmu je smeh nad ozbiljnim kategorijama neophodan. Feminizmu bez sumnje i dalje su potrebne vlastite forme

\footnotetext{
${ }^{16}$ Fuko, M., „Moći i strategije“ u Moć i znanje. Odabrani spisi i razgovori 1972 - 1977, Mediterran Publishing. Novi Sad 2012., str. 142 - 143.

${ }^{17}$ Up. Mikkola, M, „Feminist Perspectives on Sex and Gender“, The Stanford Encyclopedia of Philosophy, Winter 2017 Edition, (Edward N. Zalta, ed.), https://plato.stanford.edu/archives/win2017/entries/feminism-gender/. Pristup: 18. 02. 2019.
} 
ozbiljne igre.“18 Ozbiljno teoretisanje svakako se nastavlja razvijati kao i borba protiv neravnopravnosti, ali snagu argumentacije $\mathrm{i}$ jačinu aktivizma ne mogu uzdrmati ni smijeh ni parodija.

Rod kao kategorija i dalje stoji, nije sporno, ali više ga ne sagledavamo u odnosu na pol. Rod je važan za tijela i tjelesno uopšte i on jeste u središtu mreže društvene konstrukcije i ona jeste nešto što kroz cjelokupan istorijski razvoj patrijarhalnog društva uobličava načine na koje ljudska bića treba da se ponašaju da bi bila prihvaćena i priznata. Svako odstupanje jeste ono što ugrožava. Ono što je na kraju 20. vijeka kada na jednoj strani imamo razobličene patrijarhalne obrasce i razvijene feminističke teorije, a na drugoj $\mathrm{i}$ istovremeni uspon novih formi antifeminističkih tendencija - bilo jasno jeste da je neophodno bliže sagledati šta zapravo predstavlja rod. Ono što se pokazalo nakon nekoliko decenija razvoja ženskih pokreta, feminističkih i rodnih teorija, borbe za prava homoseksualnih i transrodnih osoba jeste to da je ostvaren pomak $\mathrm{u}$ razobličavanju strategija opresije, ali da one nisu dokinute već se ubrzano transformišu donoseći nove prijetnje. ${ }^{19}$ Džudit Batler pravi radikalni zaokret u feminističkoj teoriji upravo polazeći od toga da on ne može ugroziti feminističko djelovanje, već da predstavlja svojevrsno buđenje. „Izgleda da je neophodno da se u okvirima feminističke političke prakse na radikalno drugačiji način misle ontološke konstrukcije identiteta, da bi se formulisala predstavljačka politika koja bi feminizam mogla da oživi na nekim drugim osnovama.“ ${ }^{\text {20 }}$

Rod shvaćen samo kao okvir koji je kroz istoriju nametnulo patrijarhalno društvo pretpostavljao bi i jasan način borbe - ukazivanje na te postavljene granice i njihovo proširivanje ili ukidanja. Raskrinkavajući najprije ono što ih ograničava u javnom i privatnom životu, a onda $i$ osmišljavajući jasne politike i strategije borbe, feministkinje su tokom 19. i 20. vijeka širile granice slobode za žene. Klasični primjer za to jeste borba sifražetkinja za pravo glasa, jer se smatralo da tek kad bude

\footnotetext{
${ }^{18}$ Batler, Dž., Nevolja s rodom. Feminizam i subverzija identiteta, str. 37.

${ }^{19}$ Up. Karapetrović, M., (2012), „U sjeni avatara. O (re)konstrukciji ženskog identiteta“, Filozofska istraživanja, god. 32, sv. 1, Zagreb, str. 35 - 37.

${ }^{20}$ Batler, Dž., Nevolja s rodom. Feminizam i subverzija identiteta, str. 53
} 
postojala mogućnost da učestvuju u biranju onih koji odlučuju, ali i da budu same u mogućnosti da učestvuju u donošenju odluka žene mogu da se izbore i za ostala prava. Pojedine feminističke aktivistkinje i teoretičarke već tada su shvatile da je to tek početak borbe za ravnopravnost i da će ta borba zahtjevati nove strategije i drugačije formulisanje ciljeva. Tako anarhistkinja Ema Goldman (Emma Goldman) još 1910. godine naglašava: „Sada je žena suočena sa nuždom da se oslobodi oslobođenja, ako doista želi biti slobodna. To može zvučati proturječno, ali je ipak samo odveć istinito.“21 Kako upravo uklapanje u određene emancipatorske prakse djeluje kao novi vid sužavanja prostora za egzistenciju i djelovanje žena jasno je osam decenija poslije i na to upozorava Batler: „Feministička kritika bi trebalo da razume i kako kategoriju 'žena', subjekt feminizma, proizvode i zauzdavaju one strukture moći posredstvom kojih se teži emancipaciji.“222

Zato se opet vraćamo pitanju: kako objasniti rod imajući u vidu sve prethodno? Ako se na trenutak vratimo u polje stvarnosti, u zajednicu oblikovanu određenim politikama, i bez detaljnije analize, lako se bilježe brojni primjeri sistematskog ili djelimičnog potčinjavanja izraženog u konačnom obliku nasilnog akta nad: ženama; onima koji su zarobljeni između dva jasno određena roda i pola ili egzistiraju na granicama rodnih uloga i rodnih identiteta; onima koji istupaju iz heteroseksualne matrice; muškarcima koji ne žele biti zarobljeni untar granica maskulinosti. Postojeće politike identiteta koje se strateški primjenjuju feministički pokreti i udruženja homoseksualnih i transrodnih osoba tek u jednom dijelu se pokazuju djelotvornim, ali to njihovo djelovanje pokazuje se i nedovoljnim za krajnje dokidanje neravnopravnosti u društvu. „Kraće rečeno, odvajanjem roda od spola sveden je spol na društveno prihvatljivu i 'samorazumljivu' razinu u korist onih kojima je bilo do djelomične preraspodjele društvenih uloga, a na štetu onih koje ta

\footnotetext{
${ }^{21}$ Goldman, E., „Tragedija ženske emancipacije“ u Anarhizam i drugi ogledi, DAF, Zagreb 2001., str. 106.

${ }^{22}$ Batler, Dž., Nevolja s rodom. Feminizam i subverzija identiteta, str. 49.
} 
djelomična preraspodjela ne zahvaća i ne može zadovoljiti.“23 ${ }^{23}$ Da li to znači da sam rod nije u dovoljnoj mjeri objašnjen i teorijski predstavljen, jer na njemu se temelje i same politike? Šta je to što upravo unutar određenja roda predstavlja barijere koje ne dozvoljavaju da se stvore djelotvorne strategije otpora? Da bismo došli bar do djelomičnih odgovora treba da sagledamo mehanizme prisile koji obilježavaju sadašnja određenja roda, kao i ono što kroz stalno iskazivanje prisile ne dozvoljava proširenje određenja roda. Sve to može biti dokučeno putem diskurzivnih analiza, te po Batler: „Rod je stilizovanje tela koje se ponavlja, skup ponavljanih radnji u izrazito rigidnom regulatornom okviru koji se vremenom zgrušava i proizvodi privid supstancije, prirodnog bića. “24

Rod nije vezan za određeno tijelo, već za tijela uopšte i predstavlja svojevrstan društveni model čija moć ne djeluje samo iz spoljašnjosti na tijela već se učitava u sama tijela koja bivaju raspoređena u jedan ili drugi model. To nije radnja koja je jednom izvršena i završena, već su to procesi koji putem datih radnji učvršćuju modele i zadržavaju ih stalno unutar zarobljavajućih matrica i svoju snagu crpe upravo iz mehanizama moći koji naizmjenično ili istovremeno djeluju na liniji spolja - unutra i obrnuto. Ponavljanje je ono koje stvara iluziju, pa možemo govoriti o ,sedimentaciji rodnih normi ${ }^{425}$, koje privid trajnosti obezbjeđuju trajanjem u dužem vremenskom periodu. Rod je vezan za kolektivitete i međusobne relacije unutar grupa i pretpostavlja poštovanje norme, pri čemu norme, slijedeći Fukoa, razlikujemo od pravila i zakona i upućeni smo na govor o normalizaciji. ${ }^{26}$ Rod se sada može pokušati razumjeti kao aparat i mehanizam putem kojih se proizvodi kako

\footnotetext{
${ }^{23}$ Polić, M., ,Rod u dekonstrukciji i rekonstrukciji spola“ u Filozofija i rod (ur. G. Bosanac, H. Jurić i J. Kodrnja), Hrvatsko filozofsko društvo, Zagreb 2005., str. 200.

${ }^{24}$ Batler, Dž., Nevolja s rodom. Feminizam i subverzija identiteta, str. 104.

${ }^{25}$ Ibid., str. 283.

${ }^{26}$ Up. Butler, J., „Rodne regulacije“ u Raščinjavanje roda, str. 38.
} 
„muževno/muško i ženstveno/žensko“ u stvarnosti tako i „pojmovi muževnog/maskulinog i ženstvenog/femininog ${ }^{\text {“27 }}$ u teoriji.

Nevolja s rodom započinje govorom o potrebi da ne zaboravimo važnosti smijeha i parodije, ali upravo ono što se u ograničavajućim akademskim diskursima doživljava kao svojevrsno nadiranje neozbiljnosti i banalnosti omogućava razotkrivanje svijeta istinske tragedije ljudskih bića koja su zarobljena u unaprijed datim i nepromjenljivim rodnim određenjima. Ilustrujući parodijsko primjerima vezanim za transrodnost (drag) Batler postavlja to glavno pitanje: „Da li biti žensko uspostavlja neku 'prirodnu činjenicu' ili kulturni performans, ili se 'prirodnost' uspostavlja diskurzivno ograničenim performativnim činovima koji proizvode telo posredstvom kategorija pola i unutar njih?“28 Nastojanje da se odgovori na ovo pitanje znači uspostavljanje potpuno nove pozicije unutar feminističkih teorija. To je subverzivno djelovanje koje se ne može zadržati na već uspostavljenim kategorijama već ih mora preispitivati, prelaziti njihove granice, preformulisati. Baviti se novim značenjima roda, znači otići još dalje preispitati i pojam pola, koji nam se čini sasvim jasnim, neupitnim, čvrsto povezan sa biološkim.

\section{O TJELESNOSTI, SUBJEKTIVNOSTI I RANJIVOSTI}

Kako rod, shvaćen kao društveni konstrukt, jeste zapravo ono što u sebi samom nosi regule, norme, prisilnost i moć, tako i pol može biti shvaćen tek kada se isto primjeni na njega. Pol, a i sama tijela, ne mogu biti više prihvaćeni kao ono pasivno, ono čime tek gospodarimo, to je ,jedna od normi koje 'nekom' omogućavaju da živi, to jest koje osposobljavaju telo za život u području kulturne inteligibilnosti،‘29. Sasvim neočekivano, subjekt(i) bivaju stavljen(i) pod znak pitanja iz pozicije koje do sada nije smatrana relevantnom. Zaboravljena, pasivna tijela pokazuju da nisu samo podrazumijevana osnova egzistencije već

\footnotetext{
${ }^{27}$ Ibid., str. 39.

${ }^{28}$ Batler, Dž., Nevolja s rodom. Feminizam i subverzija identiteta, str. 38.

${ }^{29}$ Batler, Dž., Tela koja nešto znače: o diskurzivnim granicama 'pola', Samizdat B92, Beograd 2001., str. 14.
} 
prostor koji služi za učitavanje, označavanje, oblikovanje, formulisanje. Tijela nam pokazuju: „dinamiku moći u kojem se ona ne može odvojiti od regulativnih normi“; performativnost kao „reiterativnu moć diskursa da proizvode pojave kojima upravlja i ograničava“; da pol nije određen rodom već je „kulturna norma koja upravlja materijalizacijom tela“; da ona nisu mjesta trpljenja već oblikovanja; da se otvara pitanje identifikacije i u tom smislu šta je sve do sada bilo isključeno tj. kako su se proizvodila „odbačena bića““. ${ }^{30}$

U nastojanju da objasni teoriju o rodu i odgovori na kritike, Batler se prvenstveno fokusirala na preciziranje termina performativnosti, što je je vodilo ka otvaranju teme tjelesnosti i stavljanja u prvi plan samih tijela. Pokušati drugačije razumjeti rod i pol neminovno nas je vodilo ka razmatranju pitanja, šta jesu tijela, možemo li i na koji način govoriti o tjelesnosti, te na kraju i o materijalnosti uopšte. To više ne predstavlja samo zaokret u feminističkoj teoriji, već otvara put ka pitanjima koja dodiruju osnove filozofije. U feminizmu od samog početka tijelo jeste u prvom planu, ali sama teorija bavi se ovim problemom u većoj mjeri tek od trećeg talasa. Za filozofiju tijelo nikad nije moglo da bude među glavnim temama, jer bi ugrožavalo predstavu univerzalnog razuma i uma, predstavu o biću potpuno odvojenom od onog konačnog, ranjivog, lomnog. Lis Irigare (Luce Irigaray), s kojom je Džudit Batler često u raspravi, analizirajući Platonov dijalog Timaj o autističnosti filozofije kaže: „Zaista u cilju očuvanja integriteta Očeve slike, filozofska optika lišava Biće svega onoga što u univerzumu nalikuje Očevoj upotrebi svih čula, svega što bi moglo da generiše njegovo smenjivanje. Daje mu, naravno, sferičnu formu, najsavršeniju od svih figura, najviše nalik samoj sebi, spoljnih ivica uglačanih do savršenstva. “'31

To savršenstvo je ugroženo već samim govorom o tijelu, a još više uspostavljanjem pitanja pola i roda. Ipak, u prvim talasima feminizma kada dominira aktivizam, zahtjevi za promjenom u društvu,

\footnotetext{
${ }^{30}$ Ibid., 15.

31 Иригаре, Л., Speculum другог: жена, Издавачка књижарница Зорана Стојановића, Нови Сад, Сремски Карловци 2014., str. 401.
} 
manifesti, kada se svaki tekst i knjiga o potlačenosti žena označava kao nešto neobjektivno, nenaučno i u krajnjem slučaju nebitno, taj govor koji ne interveniše u filozofiju, i dalje je ostavlja sigurnu u utvrdi patrijarhalnog. Razvoj feminizma kao teorije koja se više ne zaustavlja samo na opštim pitanjima o rodnoj asimetriji, već ide u pravcu preispitivanja ključnih pojmova iz različitih naučnih oblasti, sada više ne samo da dodiruje već i uzdrmava zidove filozofskih kanona. Posebno kada više nije riječ o teoretičarkama koje se bave feminističkom i rodnom teorijom uopšte, već kad je riječ o feminističkim filozofkinjama koje govore i pišu o feminizmu iz filozofije i o filozofiji iz feminizma. Džudit Batler, pri tome, čini još jedan ključni korak - ne polazi ka filozofiji čvrsto braneći osnovne feminističke principe, već prvo kritikuje sam feminizam da bi mogla kritičku oštricu da usmjeri prema filozofiji. Na taj način stvara nevolje i jednoj i drugoj strani. Već prije toga postmoderne teorije su ispostavile niz pitanja na koje je kanonska filozofija na početku odgovarala tek odbijanjem, otvaranje dijaloga sa zakašnjenjem bila je neminovnost, jer su preispitivani glavni filozofski pojmovi. Sve te promjene bilježimo prvo u društvenim naukama, kao što su antropologija i sociologija, te tako zaobilaznim putem filozofija biva potaknuta na promjenu. „Dekonstrukcija prosvetiteljskog, racionalističkog, univerzalnog subjekta, koji je do sada imao isključivo muški lik, pruža se ozbiljna mogućnost konstrukcije drugačijeg, višedimenzionalnog subjekta ili, bolje rečeno, mnoštva subjekata. ‘32

Razvijanje rasprava o rodu, polu, tijelu (tjelesnosti) unutar feminističke filozofije, bez obzira koliko ona bila marginalizovana unutar filozofije, nužno je značila i bavljenje subjektom uopšte. Samo je bilo važno shvatiti da ono što je predstavljano kao glavna slabost samo marginalizovanje - sada znači mogućnost drugačijeg promišljanja, činjenja zaokreta neophodnog za oživljavanje teorije. „Ako hoćemo nešto da dovršimo moramo da ignorišemo to da će, i pored svih priprema, kraj biti neodređen. To ignorisanje nije aktivno zaboravljanje, to je, zapravo, aktivno marginalizovanje žitkosti,

${ }^{32}$ Papić, Ž., Polnost i kultura: telo i znanje u socijalnoj antropologiji, XX vek, Čigoja štampa 1997., str. 26. 
glibovitosti, nedostatka čvrstog tla na marginama, na početku i na kraju. “33 Istovremeno razumijevajući teorijski marginu upravo na taj način i suočavajući se životima onih koji žive na margini, Džudit Batler nas upućuje na ključna filozofska pitanja: Šta jeste subjekt? Šta jeste život? Da li su prava ljudska ili ostaju tek formalna prava? Kako se proizvodi moć i u kojoj mjeri nas zarobljava? Kojim putem da idemo da bismo bili dostojanstvena ljudska bića uprkos strahu od vlastite krhkosti i ranjivosti?

Istraživanja na tragu ovih pitanja za savremene feminističke teoretičarke/filozofkinje, predstavljaju i stalno nastojanje da pokažu u kojoj mjeri je razvoj teorije toliko značajan u savremenom društvu iako to teoretsko danas sve češće biva ostavljeno po strani. Razotkrivanje pojma roda tek je jedna od polazišnih tačaka koja bi upravo filozofiji omogućila da se odmakne od svojih tradicionalnih okvira. Preispitivanje stvarnosti upravo sa nekih drugačijih (i danas marginalnih) feminističkih pozicija, stvara dobru platformu za otvaranje i daleko šireg pitanja, kao na primjer, uopšte o subjektima koji sami sebe već počinju razumjevati kao Drugost u suočavanju sa vještačkom inteligencijom. Tim pitanjem, $u$ okviru govora o humanom $i$ posthumanom, kao i redefinisanju oblasti humanistike, posebno se bavi Rozi Brajdoti (Rosi Braidotti) koja naglašava: „Nehumano više nije ono što je nekad bilo. Odnos između humanog i tehnološkog drugog, kao i afekti koje taj odnos podrazumeva, uključujući želju, surovost i bol, radikalno se menja sa savremenim tehnologijama naprednog kapitalizma." ${ }^{34}$ Brajdoti se tako usmjerava kako na metateorijsko razmatranje pozicije same filozofije i teorije u novo doba, tako i na pitanje preobražavanja shvatanja materijalnosti koji uključuje i naša tijela i našu tjelesnost. $O$ tome takođe brine i Džudit Batler kada se u svojim kasnijm tekstovima prvenstveno okreće tom subjektu savremenosti čija ranjivost, posebno kroz razumijevanje vlastitog tijela

\footnotetext{
${ }^{33}$ Spivak, G. Č., Kritika postkolonijalnog uma, Beogradski krug, Beograd 2003., str. 239.

34 Brajdoti, R., Posthumano, Fakultet za medije i komunikacije Univerzitet Singidunum, Beograd 2016., str. 143.
} 
u političkim okvirima, u potpunosti dolazi do izražaja. „Ako nismo u stanju da mislimo o ranjivosti, ne možemo misliti ni o otporu. Misleći o otporu, mi već uklanjamo otpor prema ranjivosti upravo da bismo pružili otpor." ${ }^{\text {(35 }}$

\section{ZAVRŠNA RAZMATRANJA}

Dekonstruisanje roda koje nadilazi i kritikuje konstruktivistički pristup može biti i jeste osnova za rekonstrukciju roda. Suočavanje sa preispitivanjem esencijalističkog i konstruktivističkog ne otvara samo niz novih problema u feminističkim teorijama, već ponovo podstiče $\mathrm{i}$ poziva na preispitivanje ključnih pojmova unutar filozofije kao što su, na primjer, biće, identitet, ontologija, sloboda, moć, znanje. Predstavnici glavnih tokova filozofije nastoje se i danas zadržati na temeljima tradicionalnih pristupa i davno utvrđenih kanona, ali jasno je da ako ne sagledaju pozive za dijalog koji im stižu iz različitih oblasti, ovdje konkretno iz feminizma, mogu biti osuđeni na zatvaranje u vlastitu tvrđavu. Za razliku od perioda prvog i drugog talasa feminizma kada još uvijek u velikoj mjeri nije bila razvijena feministička i rodna teorija, od trećeg talasa feminizma - kada su već uspostavljeni i pojmovi i metodologija i prošireno polje teoretskog rada - filozofija više nema opravdanje za ignorisanje i zanemarivanje onog što je dugo isključivano. Upravo to nam pokazuju temeljne postavke teorije Džudit Batler.

Sve dok postoji mogućnost da se filozofija zadrži u krutim okvirima postojećih pravaca koji se na neki način verifikuju i time što se potvrđuju kroz svoju makar i kratku istoriju, bez obzira na otpor i prema njima (na primjer, postmoderna/poststrukturalistička filozofija), teme i načini istraživanja unutar tih oblasti će od onih koji pretenduju na ulogu kanonskih filozofa biti bar u jednom dijelu priznate. Feministička filozofija, iako imenovana, prvenstveno od samih žena u filozofiji koje se bave i feminističkom teorijom, i dalje predstavlja onu

${ }^{35}$ Batler, Dž., „Ranjivost i otpor“, Filozofija i društvo, Vol. 27, No 1, 2016., str. 52. 
neuralgičnu tačku prema kojoj se zauzima stav ignorisanja ili odbacivanja. Feminističke teoretičarke ili feminističke filozofkinje, svjesne značaja neminovnosti promjena paradigmi i otvaranja prema novim poljima istraživanja, zaobilaze te igre moći sazdane na pravilima koje unaprijed utvrđuju pobjednike, te se posvećuju razotkrivanju problema sadašnjice ne plašeći se da će u pojedinim momentima biti označene kao one koje više ne pripadaju filozofiji.

\section{LITERATURA}

Arent, H., Život duha, Službeni glasnik i Alexandria Press, Beograd 2010.

Bovoar, S. de, Drugi pol, I-II, BIGZ, Beograd 1982.

Batler, Dž. Nevolja s rodom. Feminizam i subverzija identiteta, Karpos, Loznica 2010.

Butler, J., „Može li 'Druga' filozofije govoriti? “ u Raščinjavanje roda, Šahinpašić, Sarajevo 2005.

Batler, Dž., „Ranjivost i otpor“, Filozofija i društvo, Vol. 27, No 1, 2016.

Batler, Dž., Tela koja nešto znače: o diskurzivnim granicama 'pola', Samizdat B92, Beograd 2001.

Brajdoti, R., Posthumano, Fakultet za medije i komunikacije Univerzitet Singidunum, Beograd 2016.

Fuko, M., „Moći i strategije“ u Moć i znanje. Odabrani spisi i razgovori 1972 1977, Mediterran Publishing, Novi Sad 2012.

Goldman, E., „Tragedija ženske emancipacije” u Anarhizam i drugi ogledi, DAF, Zagreb 2001.

Иригаре, Л., Speculum другог: жена, Издавачка књижарница Зорана Стојановића, Нови Сад, Сремски Карловци 2014.

Karapetrović, M. U lavirintima bića. Ontološka rasprava, Filozofski fakultet Univerzitet u Banjoj Luci i Grafid, Banja Luka 2014.

Karapetrović, M., „U sjeni avatara. O (re)konstrukciji ženskog identiteta“, Filozofska istraživanja, Zagreb, god. 32, sv. 1, 2012.

Papić, Ž., Polnost i kultura: telo i znanje u socijalnoj antropologiji, XX vek, Čigoja štampa, 1997.

Polić, M., „Rod u dekonstrukciji i rekonstrukciji spola“ u Filozofija i rod (ur. G. Bosanac, H. Jurić i J. Kodrnja), Hrvatsko filozofsko društvo, Zagreb 2005.

Spivak, G. Č., Kritika postkolonijalnog uma, Beogradski krug, Beograd 2003. 
Mikkola, M, "Feminist Perspectives on Sex and Gender", The Stanford Encyclopedia of Philosophy, Winter 2017 Edition, (Edward N. Zalta, ed.), https://plato.stanford.edu/archives/win2017/entries/feminismgender/. Pristup: 18. 02. 2019.

\title{
MILENA KARAPETROVIĆ \\ University of Banja Luka, Faculty of Philosophy \\ ONTOLOGY OF GENDER: FEMINIST UNDERSTANDING OF PHILOSOPHY
}

\begin{abstract}
The establishment of gender as an analytic category has significantly influenced the discussions on all important issues in the humanities and social sciences, but it still prefers to bypass than, what was included in the mainstream of philosophical debate. Although feminist philosophy and philosophy of gender entered the framework of the curriculum at most departments of philosophy, they have remained in the margins in their own protected areas. Instead of directing attention at the open question about the reasons for leaving feminist and gender theories on the margins of philosophy, this will be considered an important turn within these theories that is the hub in their development. It is a feminist philosophical concept Butler, presented before three decades, which today opens opportunities for new positioning, despite the troubles it brings. The papers are primarily framed her works: Gender Trouble, Bodies that Matter, and Undoing Gender.
\end{abstract}

Keywords: feminism, gender, sex, philosophy, performativity, Otherness, subject, body

Primljeno: 19.2.2019.

Prihvaćeno: 9.5.2019. 